University of Nebraska - Lincoln

DigitalCommons@University of Nebraska - Lincoln

Mammalogy Papers: University of Nebraska

State Museum

Museum, University of Nebraska State

1948

Mule Deer Record for Minnesota

Harvey L. Gunderson

University of Minnesota

Follow this and additional works at: https://digitalcommons.unl.edu/museummammalogy

Part of the Zoology Commons

Gunderson, Harvey L., "Mule Deer Record for Minnesota" (1948). Mammalogy Papers: University of Nebraska State Museum. 152.

https://digitalcommons.unl.edu/museummammalogy/152

This Article is brought to you for free and open access by the Museum, University of Nebraska State at DigitalCommons@University of Nebraska - Lincoln. It has been accepted for inclusion in Mammalogy Papers: University of Nebraska State Museum by an authorized administrator of DigitalCommons@University of Nebraska Lincoln. 


\section{MULE DEER RECORD FOR MINNESOTA}

During the hunting season of 1947, Leonard Nygren shot a deer near Pillager, Cass County, Minnesota. The deer, which weighed 153 pounds dressed, was disqualified in a sportsman's contest because it was not considered a white-tailed deer, according to a newspaper report. The report was investigated and the animal in question was identified as a mule deer, Odocoileus hemionus. This extends the known range of this deer in Minnesota nearly 100 miles to the east. John Jarosz, Museum Preparator, and the writer went to Nygren's place nine miles north of Pillager and measured and skinned the animal which is now specimen number 2457 in the Minnesota Museum of Natural History collection. The total length of the animal was 72 inches, the ears were 10 inches, the metatarsal gland was 7 inches long, and the tail had a black tip. The vertical tine of the antler was not dichotomously branched, although quite long.

This is the first Minnesota record of a mule deer since 1941, when one was killed in Atlanta Township, Becker County, by a car. That specimen is number 1924 in the collections of the Minnesota Museum of Natural History.

Swanson, Surber and Roberts in "Mammals of Minnesota" (Minn. Dept. Conser., Tech. Bull. 2: 99, 1945) state, "The mule deer was found originally in western Minnesota at least as far east as northeastern Marshall County and possibly further, because it is a wide ranging animal."-HARVEY L. Gunderson, Minnesota Museum of Natural History, Univeristy of Minnesota, Minneapolis, Minnesota. Received January 18, 1948. 